\title{
The correlation between students' motivation and their vocabulary size at eleventh grade
}

\author{
Aji Prayugo ${ }^{1}$, Cucu Sutarsyah ${ }^{2}$, Fajar Riyantika ${ }^{3}$ \\ English Education Study Program, University of Lampung ${ }^{1,2,3}$ \\ ${ }^{1}$ ajiprayugo29@gmail.com
}

\begin{abstract}
This research aims to find the correlation between students' motivation and vocabulary size and investigate the extent to which student motivation affects students' vocabulary size. This research is quantitative research by using the correlation method. In taking the sample, the researcher used the purposive sampling technique. The number of the sample is 30 students at XI IPA 1 SMA N 1 Jati Agung. The instrument of this research was a questionnaire and vocabulary size test. There were 50 multiple-choice items for the vocabulary size test and 30 items for the students' motivation questionnaire. The finding showed that there is correlation between students' motivation and their vocabulary size. The coefficient correlation was higher than the critical value of the r-table $(0.708>0.361)$. It also found that students with high motivation could get $30 \%-60 \%$ higher scores than students with low motivation; it assumed that student' motivation affects students' vocabulary size.
\end{abstract}

Keywords: correlation, students' motivation, students' vocabulary size

\section{INTRODUCTION}

Motivation is an internal factor that affects learning. For example, Nunan (2003) says that motivation and learning attitudes are significant predictors of achievement. In connection with this statement, Slavin (2011) says that students who have high motivation to learn something are more likely to be active than others to consciously plan their learning, implement lesson plans, and store the information they get.

High motivation will supply positive energy in learning English.Students will be better prepared to be involved in the teaching and learning process in the classroom. Highly motivated students will choose to read more books, ask the teacher lots of questions, do exercises, expose the use of English, try to use their English skills to communicate with others, and happily engage in the teaching and learning process of English.Meanwhile, students with low motivation usually do not have a strong interest in the teaching and learning process. They rarely ask even though they do not understand the topic. They will be forced by teachers or parents to read books, practice questions, and do assignments.

Low-motivation students usually perceive English as the most challenging subject to learn. Thus, Low or high motivation in learning English ultimately affects learning outcomes. In addition, high motivation has encouraged and supported students to try their hardest to master English subjects. Intrinsically motivated students' do better in classroom activities because they are excited to learn new things. 
Besides the students' motivation, the following discussion is related to vocabulary owned by students. Vocabulary is the essential language aspect that must be mastered before mastering English skills. According to Hatch and Brown (1995), vocabulary is a list or set of words for a particular language or a list or set of words that individual language speakers might use. From the definition above, we can say that vocabulary is all the words in a familiar language and used by a person to communicate with others. Before talking about communication using a foreign language, two skills must be mastered by students, namely receptive and productive skills. Receptive skills are listening and reading, while productive skills produce words, either oral or written, speaking and writing. Each student has a different vocabulary size; therefore, vocabulary size can help to analyze the number of vocabularies owned by students, both students who have high and low motivation. Vocabulary size refers to the number of words a person knows. The vocabulary size test measures how many words the learner knows. Vocabulary size usually measures learner's knowledge of word forms and the ability to relate these forms to meaning.

Tarigan (1984) states that language skills are primarily dependent on vocabulary size.Dealing with vocabulary size, English learners cannot develop other language elements, both pronunciation, grammar, and spelling, if they only have limited vocabulary. By enriching vocabulary, students will gain adequate understanding in receiving or producing words.

As explained above, vocabulary is essential in learning English. Wallace (1982) states that vocabulary is a vital aspect of language. It can be ascertained that someone cannot use the language they want to master well without a good vocabulary size.Students should have a lot of vocabulary because a lack of vocabulary often brings problems for English learners. Therefore, the conclusion cannot be denied that vocabulary is one of the essential things in English communication.

\section{METHODS}

This research is a quantitative study to determine the correlation between students' motivation and their vocabulary size. The test was given two types, for vocabulary size, a vocabulary size test would be given as many as fifty items in which there were 2000-3000 words level.To deal with the vocabulary size test, the researcher created the test based on the words family list by Nation (1983).However, to see students' motivation, 30 questionnaires will be given related to students' motivation in learning English. In order to see is there a positive relationship between student motivation and vocabulary size, the percentage of student interest or student motivation would be compared with the results of the vocabulary size test. In other words, if the students have high motivation to learn English and have high vocabulary scores, this research prove that there is a positive correlation between student' motivation and their vocabulary size. To find out the correlation between students' motivation and students' vocabulary size, the researcher used design by Karl Pearson in 1896 (Pearson, 1896), the design of the research as follows:

$\mathrm{r}=\frac{n\left(\sum x y\right)-\left(\sum x\right)\left(\sum y\right)}{\sqrt{n \sum x^{2}-\left(\sum x^{2}\right)\left(n \sum y^{2}-\left(\sum y\right)^{2}\right.}}$

Where :

$\mathrm{n}=$ Number of data pairs $\mathrm{X}$ and $\mathrm{Y}$

$\mathrm{x}=$ Total Sum of Variable $\mathrm{X}$ 
$\mathrm{y}=$ Total Sum of Variable $Y$

$\mathrm{x} 2=$ Square of Total Number of Variables $\mathrm{X}$

y2= Square of Total Number of Variables $Y$

$\mathrm{xy}=$ Multiplication Result of Total Number of Variable $\mathrm{X}$ and Variable $\mathrm{Y}$

The population of the research was the completely eleventh grade of students' of SMAN 1 JatiAgung, which consisted of 187 students divided into six groups.In selecting the sample, the researcher used purposive sampling. In this study, the researcher chose the eleventh-grade as the sample, considering that the eleventh-graders in this study would be able to do more indepth research because the eleventh-graders already had much acceptance regarding the vocabulary high school learning process. Apart from these reasons, the eleventh-grade student population has the same characteristics. There is no superior class or regular class in the class division so that students' abilities are considered equal. The division of the eleventh-grade is divided into 6 class groups. However, those who will be the objects of research are students in class XI IPA 2 consist of 30 students in which the class was dominated by students who had the capability in the English language. However, they still had some problems with English vocabulary size.

In conducting this research, the researcher used questionnaire of learning motivation and test of vocabulary sizeas the instruments. In this research, the researcher used a close direct questionnaire. The questionnaire uses the Indonesian language. There are 30 items of the questionnaire with four alternatives answers from strongly agree until strongly disagree. The students were supposed to give their answers as factual and accurate information about themselves or the information that is close to the fact as provided in the four alternative answers. For vocabulary tests, multiple-choice types would be used in this research. The multiple-choice format has some advantages. Synonym recognition was a type of multiplechoice format that the test taker tried to remember or identify the synonym of the word target.There were 50 items would be used to measure students' vocabulary size.

The researcher made the steps after conducting the research using tests; the researcher analyzed the data using the correlation in SPSS (Social Science Statistics Program). The test results are in the form of scores or interval data. After obtaining these results, the researcher would analyze the relationship between students' motivation and their vocabulary size. The result of reliability of the questionnaire was 0.877 . The reliability of questionnaire was calculated statistically by using Cronbach Alpha's which showed 0.877 that could be classified as a very high reliability. Moreover, in the reliability test of vocabulary test, it shows that the $r$ value $(0.960)$ is greater than the $r$ table $(0.361)$, it can be concluded that the vocabulary test in this study is reliable and consistent.

\section{RESULTS AND DISCUSSIONS}

\section{Results}

The result of students' motivation taken from students' questionnaire. According to the questionnaire, the levels are categorized into two interval levels, the levels are high heat and low motivation was found that more than $76.6 \%$ students have high motivation, and $27.5 \%$ students have low motivation. In short, that the most of the students are in high motivation level. It can be seen from the table below. 
Table 1. The result of student's motivation

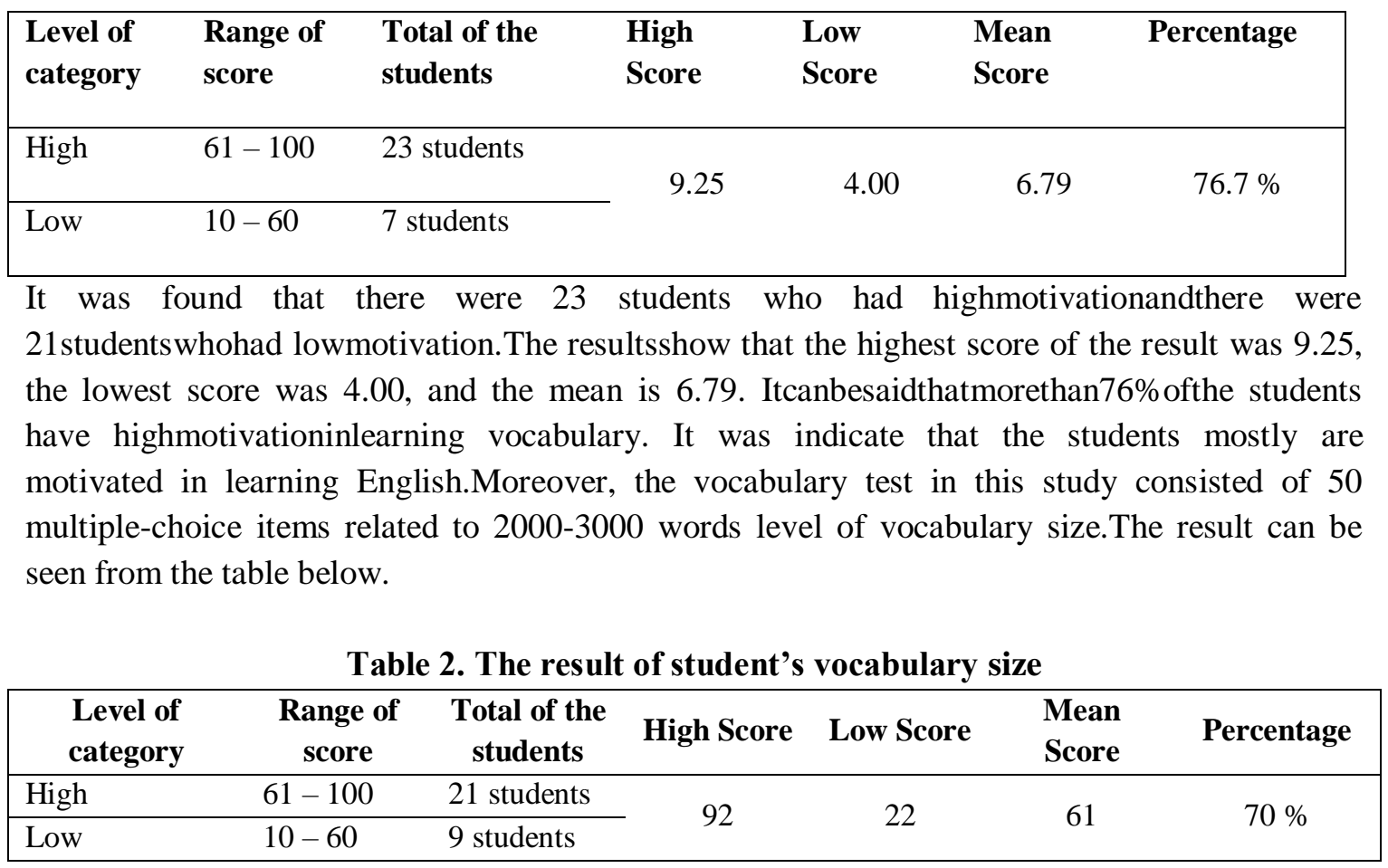

From the table above it shows that there were 21 studentswhohavehighvocabularysize test score andthere were9studentswhohavelowvocabularysize.The resultshowed that the highest score of the resultis 92 , the lowest score was 22 , and the average was 61 . It can be said that $70 \%$ of students have high vocabulary sizescore.

To investigate whether there is correlation between students' motivation and students'vocabularysize, bothvariableswereanalyzedbyusing PearsonProduct Moment Correlation on SPSS version 21. From the result, it shows that the coefficient correlation between students' motivation and their vocabulary size is 0.708 at the significant level of 0.01 . The coefficient correlation was higher than the critical value of r-table $(0.708>0.361)$.

The followingtable shows the computation result of two variables.

Table 3. The Value of Correlation between Students' Motivation and Their Vocabulary

Correlations

\begin{tabular}{|llrr|}
\hline & & Motivation & $\begin{array}{r}\text { Vocabulary } \\
\text { size }\end{array}$ \\
\hline \multirow{3}{*}{ Motivation } & Pearson Correlation & 1 &, $708^{* *}$ \\
& Sig. (2-tailed) & &, 000 \\
& $\mathrm{~N}$ & 30 & 30 \\
& Pearson Correlation &, $708^{* *}$ & 1 \\
Vocabulary size & Sig. (2-tailed) &, 000 & \\
& $\mathrm{~N}$ & 30 & 30 \\
\hline
\end{tabular}

**. Correlation is significant at the 0.01 level (2-tailed). 
From the result of data analysis, it was found that there was positive correlation between students' motivation and their vocabulary size. It can be said that motivation is an important factor in enrichingstudents' vocabulary size. Students who havehighmotivation willbe enthusiasticin the learning process. However, some students still have very low motivation. Students with low motivation usually have no enthusiasts to engage in the process of teaching and learning English.From the correlation table and explanation above, the researcher concluded that motivation was the key factor that affects students in learning vocabulary.

To deal with second research question, the researcher tried to analyze some students who have three levels of students' motivation included high, moderate and low motivation. The data can be seen below:

Table 4.4 Level of Students Motivation

\begin{tabular}{|llccl|}
\hline No & Students & Motivation score & $\begin{array}{c}\text { Vocabulary } \\
\text { test score }\end{array}$ & $\begin{array}{c}\text { Level of } \\
\text { motivation }\end{array}$ \\
\hline 1. & S1 & 111 & 98 & High \\
\hline 2. & S2 & 103 & 80 & High \\
\hline 3. & S3 & 101 & 92 & High \\
\hline 4. & S4 & 101 & 78 & High \\
\hline 5. & S5 & 76 & 66 & Moderate \\
\hline 6. & S6 & 92 & 64 & Moderate \\
\hline 7. & S7 & 87 & 68 & Moderate \\
\hline 8. & S8 & 76 & 66 & Moderate \\
\hline 9. & S9 & 48 & 24 & Low \\
\hline 10. & S10 & 57 & 38 & Low \\
\hline 11. & S11 & 51 & 48 & Low \\
\hline
\end{tabular}

Slameto (2015) states that there are several factors that affect student achievement, including intelligence, physiology, attitudes, interests, talents and motivation. Although there are several other factors besides motivation in supporting student achievement, the researcher found that motivation was sufficient to support student achievement, especially in English lessons. From the data above, it can be concluded that students who have high motivation can get $10-20 \%$ higher vocabulary test scores than students who have moderate levels of motivation. In fact, students who have high motivation can score $30-60 \%$ greater than students who have low motivation in learning English. The conclusion is motivation really helps students in developing their abilities so that better results will be obtained.

Hypothesis testing is the last step in this research to prove whether the hypothesis proposed by the researcher was accepted or not.

HI. There is a correlation between students' motivation and their reading comprehension achievement. We can accept this hypothesis if the $r$ value is higher than $r$ table.

The result of calculation for the hypothesis showed that the coefficient correlation was 0.708 , which was classified into positive correlation. The critical value of $r$-table was found 0.393 . The coefficient correlation was higher than critical value of $r$-table $(0.708>0.361)$. Therefore, for the 
first hypothesis, the null hypothesis was rejected, and the research hypothesis was accepted. It means that there was correlation between students' motivation and students' vocabulary size.

\section{Discussions}

From the result, it was found that there was positive correlation between students' motivation and students' vocabulary size. It can be said that the important factor in learning vocabulary size is students' motivation. It was strengthened by Nunan (2003) also explained that motivation and learning attitudes are important predictors of achievement. In mastering English vocabulary, students should have high motivation to make learning process easier. The success of learning depends on the level of students' motivation. Students with high motivation will be enthusiastic in the teaching learning process, so they will be easier to learn English well. In a study by (Brown, 2001) he found that motivation is a factor high or low learning objectives. In learning English, to simplify the learning process students' should have high motivation. On the other words, it can be assumed that learning success are depends on the level of student motivation. It can drive learners in achieving learning goals. Students, who were motivated they usually have the inner strength to learn, discover and utilize abilities, improve academic achievement and adapt to the demands of the school context. Thus, students who have high motivation will be enthusiastic in the learning process. However, some students still have very low motivation. Students with low motivation usually do not have a strong interest to be involved in the teaching and learning process of English. They rarely ask even though they do not understand the subject.

Based on the results of a motivation questionnaire and vocabulary test, the researcher asserts that motivation affects students' vocabulary size; Students who have high motivation tend to have good vocabulary size. From the data that was analyzed by researcher, it could be concluded that students who have high motivation can get $10-20 \%$ higher vocabulary test scores than students who have moderate levels of motivation. In fact, students who have high motivation can score $30-60 \%$ greater than students who have low motivation in learning English. From the description above, the researcher concluded that motivation is a key factor influencing students in the teaching and learning vocabulary.

\section{CONCLUSIONS AND SUGGESTIONS}

\section{Conclusions}

Theobjectiveofthisresearchwastofind outwhethertherewasasignificant correlation of students' motivation and their vocabulary size or not. In relation to results and discussion of the study, it is concluded that there is a significant correlation between students' motivation and students' vocabulary size. Statistically, it could be seen from the gain of the students' motivation questionnaire mean score and vocabulary test mean score. Students who have high motivation tends to have largevocabulary size rather than the students who havelow motivation. It proves that students' motivation influences their vocabulary size.In addition, the reason why motivation canaffect vocabularysize becausewhen studentshavegood motivation in learning English, they will do anything that can support them to improve their knowledge about English. They will also try to read an English book, watching, reading, writing many materials of English vocabulary, list their word and find its meaning, also try to create their own meaning, so that their vocabulary size could increase better. 


\section{Suggestions}

In reference with the conclusion, the researcher gives some suggestions. The first for English teachers are hoped can give motivation to the students tobuild their interest in mastering English vocabulary. In addition, teacher can apply suitable strategy to make more effective learning experience andenjoyment among the students. Since learning English turns to be easier by using kind of media, teachershouldhave new creative ways to make students more interestin learning English,especiallyinlearningnewvocabulary. It is also suggested to extend the number of participant or student to get result that is more accurate. For example, there are 30 students as the subject in this study; the future researcher can make it 60 students or more.

\section{REFERENCES}

Hatch, E., \& Brown, C. (1995). Vocabulary, semantics, and language education. New York: Cambridge University Press, 40 West 20th Street.

Brown, K. (2001). Bilingual heritage students' languagecontact and motivation. Motivation and second language acquisition, 23.

Nation, P. (1983). The vocabulary size test.https://www. victoria.ac.nz/lals/about/staff/publications/paul-nation/Vocabulary-Size-Testinformation-and-specifications.

Nunan, David.(2003). The impact of English as a global language on educational policies andpractices in the Asia-Pacific Region. TESOL quarterly 37.4.

Pearson, K. (1896). Mathematical contributions to the theory of evolution.-III. Regression, heredity, and panmixia.London: Royal Society, 187.

Slameto, Slameto. (2015).Implementasipenelitiantindakankelas. Scholaria: JurnalPendidikandanKebudayaan, 5.3.

Slavin, R. E. (2011). Instruction based on cooperative learning. Handbook of research on learning and instruction, 4.

Tarigan, H. G. (1984). Basic principles of literature. Bandung: Angkasa.

Wallace, M. J. (1982). Teaching vocabulary.RELC Journal.London: Heinemann, 10. 